\title{
A giant squid (Architeuthis $d u x$ ) off Reunion Island, western Indian Ocean: the greatest giant ever?
}

\author{
EVGENY V. ROMANOV ${ }^{1}$, SEBASTIEN JAQUEMET ${ }^{2}$ AND LARA PUETZ ${ }^{3}$ \\ ${ }^{1}$ CAP RUN, Magasin no 10 - Port Ouest, 97420 Le Port, Île de la Réunion, France, ${ }^{2}$ UMR 9220 Entropie (Université de La \\ Réunion-IRD-CNRS), Avenue René Cassin, CS 92003, 97744 Saint-Denis Cedex 9, Île de La Réunion, France, ${ }^{3}$ Centre for \\ GeoGenetics, Natural History Museum of Denmark, University of Copenhagen, Øster Voldgade 5-7, 1350 Copenhagen, Denmark
}

\begin{abstract}
A freshly dead individual of the giant squid Architeuthis dux, presumably mutilated by a predator of bigger or comparable size, is reported from the south-western Indian Ocean in proximity to Reunion Island. The species was identified from body and beak morphology and validated genetically. The dorsal mantle length (DML) estimated from beak measurements (lower rostral length, $L R L$ ) varied between 2153 and $3060 \mathrm{~mm}$ depending on the allometric equation used. The Architeuthis dux individual described here is the biggest giant squid ever reported for the region.
\end{abstract}

Keywords: Cephalopod habitat, distribution records, lower rostral length, dorsal mantle length, total length

Submitted 21 February 2017; accepted 28 July 2017; first published online 12 September 2017

\section{INTRDDUCTION}

The giant squid Architeuthis dux Steenstrup, 1857 is an enigmatic deep-water cephalopod inhabiting temperate oceans and adjacent subpolar and subtropical waters worldwide (Cherel, 2003; Nesis, 2003; Winkelmann et al., 2013; Roper et al., 2015; Wada et al., 2015). Its biology and distribution remain obscure, despite recent technological advances, which allowed in-situ giant squid observations (Kubodera \& Mori, 2005; Schrope, 2013), and numerous records from all major oceans (Nesis et al., 1985; Re et al., 1998; Cherel, 2003; Martins \& Alvarez Perez, 2009; Winkelmann et al., 2013; Roper et al., 2015).

Life history characteristics of the giant squid are largely unknown, despite the species probably being one of the largest marine animals. Anecdotal reports of total length (TL) often approach extreme values of several tens of metres (Heuvelmans, 1968; Paxton, 2016); however, scientific literature documents considerably smaller sizes. Even scientific records of A. $d u x$ that ranged within 15-20 m TL (Kirk, 1888; Berzin, 1971, 1972) are commonly challenged (Grist \& Jackson, 2007; McClain et al., 2015; Paxton, 2016). There is also disagreement on giant squid lifespan: estimates of longevity range from 2-3 years (Gauldie et al., 1994; Lipiński, 1997; Lordan et al., 1998; Grist \& Jackson, 2007) to over 35 years (Landman et al., 2004).

In the Indian Ocean, the first report of $A . d u x$ dates back to the 19th century (Vélain, 1877), while the number of occurrences currently exceeds 100 records (Yukhov, 1974, 2014; Clarke, 1980; Mikhalev et al., 1981; Nesis et al., 1985; Cherel, 2003; GBIF, 2016; OBIS, 2016). The majority of regional $A$. $d u x$ encounters originate from temperate and

Corresponding author:

E.V. Romanov

Email: evgeny.romanov@ird.fr
sub-Antarctic waters, most of which correspond to remains recovered from predators' stomachs (usually from the sperm whale Physeter macrocephalus and various shark species), but some specimens were found floating at the surface or stranded (Vélain, 1877; Yukhov, 1974, 2014; Clarke, 1980; Mikhalev et al., 1981; Cherel, 2003). To date, the largest reported Indian Ocean giant squids reached $2200-2300 \mathrm{~mm}$ in dorsal mantle length (DML) either measured or estimated from reference parts such as the lower beak (Cherel, 2003; Yukhov, 2014).

Only two giant squid occurrences have so far been documented in the tropical area of the Indian Ocean: around Mauritius (Staub, 1993) and Reunion Island (Cherel, 2003). Several giant squids from the Mozambique Channel, mentioned in Yukhov (2014), lack georeferencing data, corresponding measurements and other details. The global distribution of giant squid, reported in Roper \& Boss (1982), also indicates a single record of the giant squid in the northern Indian Ocean; however no sampling details were provided. Here, we document the occurrence of the biggest giant squid ever discovered in the Indian Ocean, recovered in 2016 off Reunion Island.

\section{MATERIALS AND METHODS}

\section{Squid collection}

A squid specimen of several metres long (Figure 1A, B), lacking the distal part of the mantle (including the fin), was found floating at the surface waters off Saint Gilles, Reunion Island by the game fishing vessel 'Maeva 4' (12 m length overall) on 4 March 2016. The precise GPS position was not recorded, but coordinates were estimated to be $21^{\circ} \mathrm{Oz}^{\prime} \mathrm{S} 55^{\circ} \mathrm{o} 8^{\prime} \mathrm{E}$ from eyewitness statements of '5-6 nautical miles off Saint-Gilles'. Digital photographs were taken by fishermen and used for 

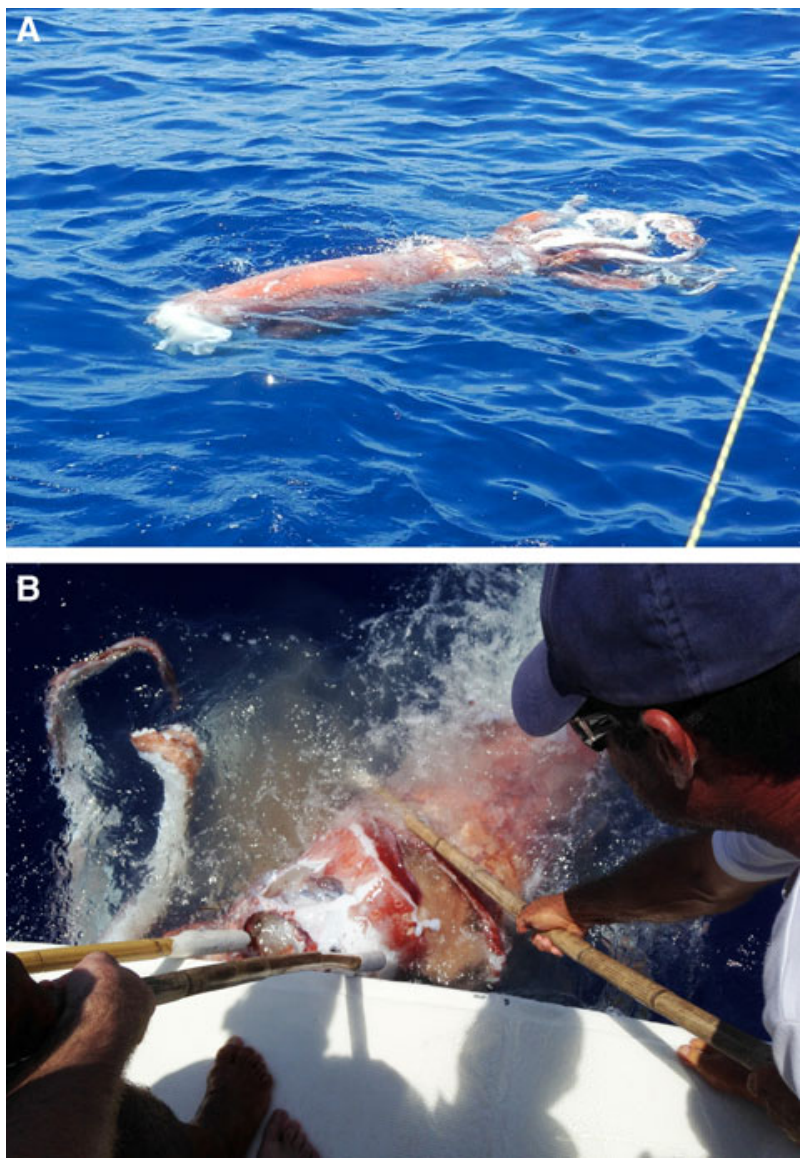

Fig. 1. The giant squid Architeuthis dux specimen at the surface, off Sain Gilles, Reunion Island on 4 March 2016. (A) Free-floating squid; (B) Attempts to pull the specimen on board by the crew of FV 'Maeva 4'.

morphological examination. Although dead, the squid did not manifest any signs of decomposition and possessed natural skin pigmentation. Due to the size and weight of the specimen and lack of suitable equipment, the vessel's crew and fishermen were unable to pull the squid onboard undamaged. Only the head with tentacles were recovered using regular fishing gaffs. Squid remains were transported to shore, where it was stored in the freezer at $-18^{\circ} \mathrm{C}$. The squid was donated by the fishermen to University of Reunion Island for further examination.

\section{Sampling}

Frozen remains of the specimen were stored for 102 days in the freezer before examination. The squid was thawed for $24 \mathrm{~h}$ at ambient temperature before sampling and measurements. Intact parts were measured with a calliper or measuring tape. The buccal mass, together with the beak, was removed from the mollusc's head prior to beak extraction. Before its preservation in $70 \%$ alcohol, the beak lower rostral length (LRL) was measured with a digital Vernier calliper with an accuracy of $0.01 \mathrm{~mm}$. Muscle tissues were sampled from the individual once thawed and stored in $96 \%$ alcohol for genetic sequencing and species identification.

\section{Genetic analysis}

Genomic DNA was extracted from $20 \mathrm{mg}$ of muscle tissue, after an overnight digest, using the automated KingFisher Duo
Prime Purification System by ThermoScientific following the manufacturer's protocol (Thermo Fisher Scientific, USA). A $313 \mathrm{bp}$ region of the mitochondrial cytochrome $\mathrm{c}$ oxidase I gene (COI) was amplified using the forward mlCOIintF- $\left[5^{\prime}\right.$ GGWACWGGWTGAACWGTWTAYCCYCC $\left.3^{\prime}\right]$ (Leray et al., 2013) and reverse jgHCO2198- [5' TAIACYTCIGGRT GICCRAARAAYCA 3'] (Geller et al., 2013) primer combination (see online Electronic Supplement 2 for laboratory specifications).

Sequence similarity searches on the query DNA sequence were done using the BLASTn search implemented on the NCBI nucleotide database (Madden, 2013) and the Hidden Markov Model (HMM) alignment tool implemented on the BOLD reference database (Ratnasingham \& Hebert, 2007).

\section{Size reconstruction}

Reconstruction of animal size from reference parts is a common approach used for damaged or digested specimens (Clarke, 1980, 1986; Hansel et al., 1988; Cherel, 2003; Staudinger et al., 2009; Potier et al., 2011). We used the giant squid beak as a reference part for further size reconstruction of the entire individual based on published allometric equations. We focused on the DML and the TL reconstruction since the former is a 'reference' length for cephalopod measurements (Roper \& Voss, 1983) while TL is commonly used for demonstration of extreme size of the giant squid among cephalopods (e.g. McClain et al., 2015; Paxton, 2016). The most robust allometric equations were selected from the literature based on the following three criteria: statistical significance (if provided by the authors), large sample size, and the $A$. dux size range covering extreme sizes of reference parts and entire squid.

The lower rostral length was used as a predictor of the DML based on Roeleveld (2000) (1) and Paxton (2016) (2) equations:

$$
\begin{gathered}
\mathrm{LRL}=11.2 \times \log _{10} \mathrm{DML}-19.3(\text { values are in } \mathrm{mm}) \\
\mathrm{DML}=e^{(-1.168+98.031 \times \mathrm{LRL})}(\text { values are in } \mathrm{m})
\end{gathered}
$$

The total length was extrapolated from the DML based on the following relationships: Paxton (2016) (3) and McClain et al. (2015) (4):

$$
\begin{gathered}
\mathrm{TL}=0.006+5.117 \mathrm{DML}(\text { values are in } \mathrm{m}) \\
\mathrm{TL}=1.59 \times \mathrm{DML}^{1.98}(\text { values are in } \mathrm{m})
\end{gathered}
$$

Records of Indian Ocean occurrences of $A$. $d u x$ from GBIF (GBIF, 2016), OBIS (OBIS, 2016) and other published records (Vélain, 1877; Yukhov, 1974; Roper \& Boss, 1982; Staub, 1993; Cherel, 2003) were used for mapping regional giant squid distribution. The Indian Ocean area is considered here following the official description of the International Hydrographic Organization: from the Asian Continent to Antarctica, with its western and eastern borders positioned at $20^{\circ} \mathrm{E}$ off South Africa and $146^{\circ} 55^{\prime} \mathrm{E}$ off Southern Australia respectively (IHO, 1953). 
Table 1. Details of the measurements of Architeuthis $d u x$ found off Reunion Island and comparisons with other large Indian Ocean giant squid individuals. LRL is lower rostral length, DML is dorsal mantle length, and TL is total length. Estimates marked by 'P' are based on Paxton (2016) equations, estimates marked by 'R' are derived using Roeleveld (2000) regression, and 'MC' corresponds to McClain et al. (2015) equation.

\begin{tabular}{|c|c|c|c|c|c|c|}
\hline \multirow[t]{2}{*}{ Sample } & \multirow[t]{2}{*}{ Date } & \multirow[t]{2}{*}{ Geographic position } & \multirow[t]{2}{*}{ State } & \multirow[t]{2}{*}{ LRL, mm } & \multicolumn{2}{|c|}{ Length, mm } \\
\hline & & & & & DML & TL \\
\hline This study & $4 \cdot 3.2016$ & $21^{\circ} 03^{\prime} \mathrm{S} 55^{\circ} 09^{\prime} \mathrm{E}^{\mathrm{a}}$ & Dead, floated at the surface & 19.74 & $\begin{array}{l}2153 \text { (99\% PI: } \\
1500-2950)(\mathrm{P}) \\
3060(\mathrm{R})\end{array}$ & $\begin{array}{l}7262(\mathrm{MC}), 11,025 \\
(\mathrm{P}) \\
14,558(\mathrm{MC}), \\
15,664(\mathrm{P})\end{array}$ \\
\hline Vélain (1877) & 2.11 .1874 & Saint Paul Island & Stranded & - & - & 7150 \\
\hline Berzin (1971) & Before 1970 & Between $35^{\circ} \mathrm{S}$ and $45^{\circ} \mathrm{S}$ & From sperm whale stomach & - & - & $19,000([s i c] 9000)$ \\
\hline Staub (1993) & $14 \cdot 5.1993$ & $\begin{array}{l}\text { Off Morne Brabant, } \\
\text { Mauritius Island }\end{array}$ & Dead, floated at the surface & - & & $4500^{b}$ \\
\hline Norman \& Lu (1997) & Before 1998 & Off Tasmania & Commercial fishing trawl & & $2400^{c}$ & \\
\hline \multirow[t]{2}{*}{ Cherel (2003) } & 18.4.1998 & $\begin{array}{l}\text { Off Saint-Paul, Reunion } \\
\text { Island }\end{array}$ & Dead, floated at the surface & $17.0-17.5$ & $1740-1930(\mathrm{R})$ & - \\
\hline & & Kerguelen Archipelago & $\begin{array}{l}\text { Beak recovered from sleeper } \\
\text { shark stomach }\end{array}$ & 18.13 & $2200(\mathrm{R})$ & - \\
\hline Yukhov (2014) & 14.4 .1969 & $37^{\circ} 10^{\prime} \mathrm{S} 65^{\circ} 56^{\prime} \mathrm{E}$ & From sperm whale stomach & - & $2300^{\mathrm{d}}$ & - \\
\hline
\end{tabular}

${ }^{\mathbf{a}}$ Estimated, see paper text for details.

b Apparently standard length.

${ }^{\mathbf{c}}$ No exact geographic position presented in the source. Specimen cannot be attributed either to Pacific or Indian Ocean.

${ }^{\mathbf{d}}$ Not an Indian Ocean record (Yukhov, 2016 personal communication).

\section{RESULTS}

\section{Remains description and identification}

The mantle, tentacles and tips of six out of eight arms were missing from the preserved remains. The head was split in two parts at the level of the eyes at the moment of squid recovery (Figure 1A, B). Measurements used for length estimates (i.e. LRL) are presented in Table 1; other measurements taken from intact parts are summarized in the Electronic Supplement 1, Table E-1. Based on the external morphology of the individual (examined from photographs and preserved remains) and on the beak morphology (Clarke, 1986; Xavier \& Cherel, 2009), the specimen was identified as the giant squid Architeuthis dux. Injuries visible on squid remains, while drifting at the surface (Figure $1 \mathrm{~A}$ ), clearly reflected an external impact: the tail and fin were missing, and the terminal part of the mantle showed naked muscles without skin.

\section{Genetics}

A $313 \mathrm{bp}$ region of the mtDNA COI gene was isolated in the specimen and the sequence was deposited in the NCBI database (accession number: KY614519). The squid query sequence returned $100 \%$ sequence similarity to the mtDNA COI region of the whole mitochondrial reference genomes and partial mtDNA COI reference sequences of Architeuthis dux stored in GenBank (Winkelmann et al., 2013; Benson et al., 2014; Kameda et al., 2015).

\section{Occurrences}

The present record of a giant squid complements previous records off the Mascarene Islands and is the third georeferenced occurrence of this species in the tropical Indian Ocean (north of the tropic of Capricorn: $23^{\circ} 26^{\prime} 13.6^{\prime \prime} \mathrm{S}$ ) (Staub, 1993; Cherel, 2003) (Figure 2).

\section{Size}

The estimated DML of the present $A$. $d u x$ specimen varied from $2153 \mathrm{~mm}$ (99\% prediction interval, PI $1500-2950 \mathrm{~mm}$ ) to $3060 \mathrm{~mm}$, depending on the equation used (Table 1). Extrapolations from DML into TL estimates suggest a specimen length ranging between 11,025 and 15,664 $\mathrm{mm}$ (Table 1).

\section{DISCUSSIDN}

The dorsal mantle length of $A$. $d u x$ reported here $(3060 \mathrm{~mm}$, estimated from equation (1)) exceeds the DML of the other Mascarene Islands specimens (Staub, 1993; Cherel, 2003) (Table 1). Cherel (2003) also estimated DML from Roeleveld's (2000) equation (1); however, direct size comparisons are less reliable with the specimen from Staub (1993) due to the ambiguous information on how measurements were taken. Comparisons of the giant squid proportions with human personages, depicted next to the specimen in photographs, suggest that Staub (1993) probably measured standard length (i.e. the length from the posterior end of the mantle to the tip of the arms) which was referred to as a 'body measurement' ('son corps mesurait') in the original paper.

In this study, the $A$. dux DML is $28 \%$ longer than the longest one reported by Cherel (2003) from the Kerguelen Archipelago (Table 1). On a global scale, our DML estimates based on Roeleveld's (2000) equation exceeds 'longest reliably measured' DML (2794 mm) (Kirk, 1880 in Paxton, 2016) reported to date, and may represent the largest giant squid ever discovered. However, Paxton (2016) suggested that Roeleveld's (2000) equation overestimates DML, at least for large individuals. Based on Paxton's (2016) regression formula, the DML estimate for our A. $d u x$ is $2153 \mathrm{~mm}(99 \%$ PI 1500-2950 mm), which makes it the largest specimen ever reported in the Indian Ocean (Table 1) and place it among the 12 largest giant squids (DML above $2000 \mathrm{~mm}$ ) 


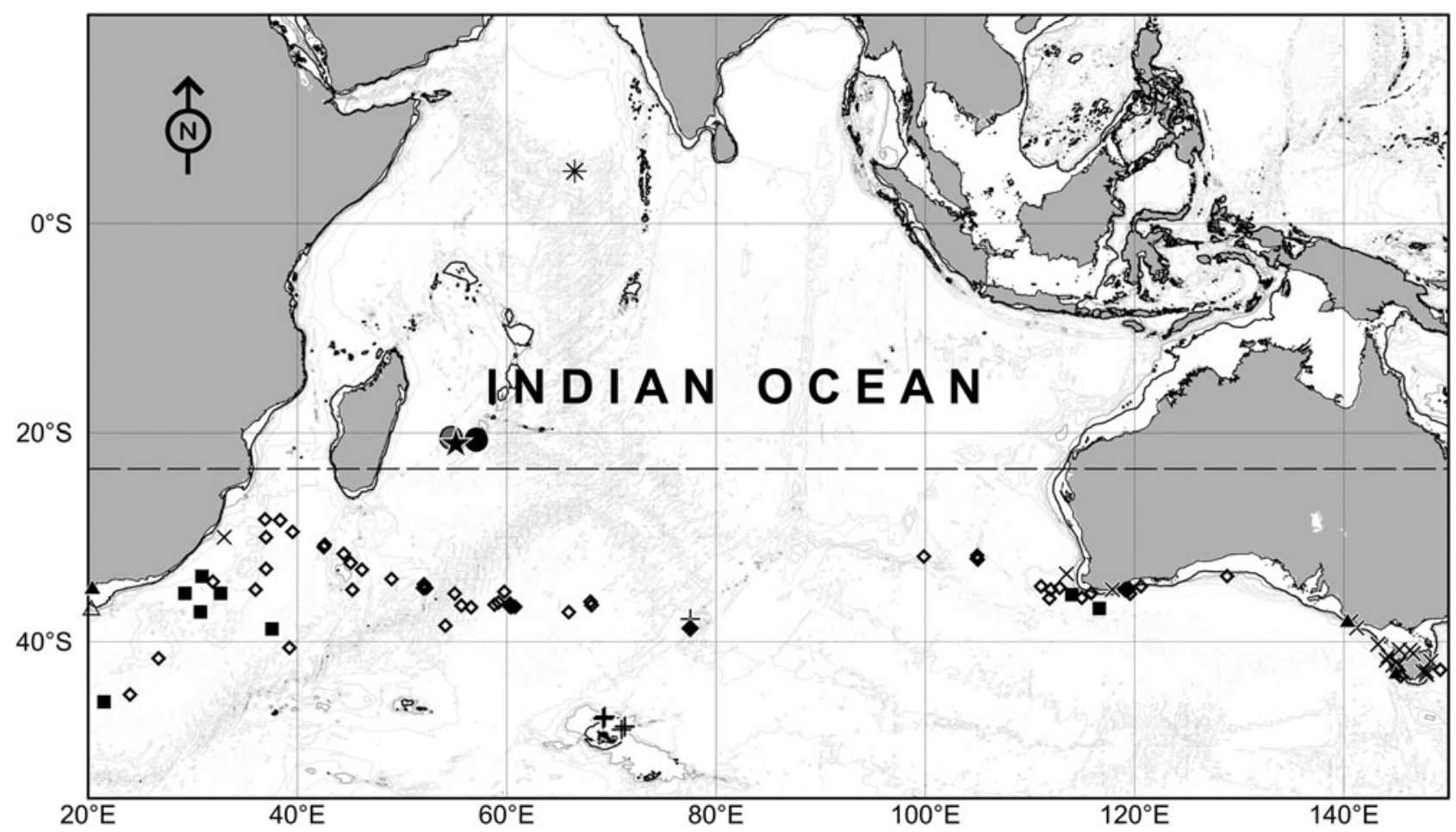

Fig. 2. The geographic positions of Architeuthis dux Steenstrup, 1857 records from the Indian Ocean. This study's record is the star; Published records: the Reunion Island record from Cherel (2003)* is the grey dot, the Staub' (1993)* record off Mauritius Island is the black dot, the black squares and snowflake are from Roper \& Boss (1982)**. The snowflake represents a single northern Indian Ocean record. The oblique crosses are data from GBIF (2016), full triangles are OBIS (2016), and crosses are from Cherel (2003). The full diamond is from the Vélain (1877) ${ }^{* * *}$ record of a stranded giant squid; the empty triangle is from Wendy West, unpublished data; the empty diamonds are from Yukhov (2016, personal communication, earlier presented as a map in Yukhov, 1974). For references marked with *, the positions of the observations were estimated from the description published in the original paper. For references marked by ${ }^{* *}$, positions were estimated from the original map presented in the paper. For references marked by ${ }^{* *}$, positions mark the central position of the island where stranding occurs. The $200 \mathrm{~m}$ isobath (dark line) and bathymetry from 1000 to $5000 \mathrm{~m}$ (in $1000 \mathrm{~m}$ steps, light lines) are shown. Coastline and bathymetry data are from GEBCO (2016).

reported globally (Kirk, 1880, 1882; Frost, 1936 in Sweeney \& Roper, 2001; Keil, 1963 in Sweeney \& Roper, 2001; Gauldie et al., 1994; Norman \& Lu, 1997).

The extrapolation of TL based on DML estimates is highly uncertain; therefore we present TL estimates only for comparison purposes with other published giant squid size records and as an indicator of a potential extreme upper range of TL. The extrapolated TL $(11,025-15,664 \mathrm{~mm})$ of the giant squid reported here (Table 1 ) exceeds the TL of an individual stranded on Saint Paul Island (7150 mm) (Vélain, 1877) and the biggest known Indian Ocean giant squid (9000 $\mathrm{mm}$ ) reported by Berzin (1971) (originally incorrectly stated as having a TL of $19 \mathrm{~m}$ ). Paxton's (2016) challenge of the $19 \mathrm{~m}$ TL size was validated by Dr Valentin Yukhov ${ }^{1}$ (2016, personal communication) who participated in the discovery of the Berzin' (1971) individual in the stomach of a sperm whale. This $19 \mathrm{~m}$ total length instead of $9 \mathrm{~m}$ appeared to be a misprint in Berzin (1971) (Yukhov, 2016, personal communication), later reproduced in the English translation (Berzin, 1972) and referenced in several papers on giant squid biology (Sweeney \& Roper, 2001; Paxton, 2016). Taking these considerations into account, size estimates of the recovered specimen described here rank at the higher end of the TL range, with the largest giant squid ever measured to be the specimen

${ }^{1}$ Dr Valentin Yukhov, Odessa Centre of YugNIRO, Odessa, Ukraine. stranded on the New Zealand coast in 1887 (Kirk, 1888) ${ }^{2}$, with 684 inches $(17,374 \mathrm{~mm})$ in TL.

Together with individuals reported by Staub (1993) and Cherel (2003), our record is the third northernmost occurrence of giant squid observed to date in the Indian Ocean. Besides an $A$. dux global occurrences map that appeared in Roper \& Boss (1982) (which was missing sampling details), giant squid have never been reported from equatorial waters nor from the northern hemisphere of the Indian Ocean. The presence of a giant squid off India as mentioned by Coro et al. $(2015)$ and based on Silas $(1968,1985)$ is obviously erroneous: the original Silas $(1968,1985)$ papers did not show any record of $A$. $d u x$ encounters in Indian waters in their oceanwide accounts of various squid species.

Global ocean records of the giant squid in the tropics are only known from the eastern tropical Atlantic (Nigmatullin, 1976; Nesis et al., 1985), demonstrating apparently the capacity of errant individuals to penetrate into tropical waters via deep, cold-water currents. The principal area of the Indian Ocean giant squid distribution seems to correspond with subtropical and temperate waters of the southern hemisphere (Figure 2) (Vélain, 1877; Yukhov, 1974, 2016, personal

${ }^{2}$ It should be noted some ambiguity exists in Kirk (1888). A length measurement of 684 inches was given in the table, while in the text he referred to a length of 55 feet 2 inches $(662$ inches, or $16815 \mathrm{~mm}$ ) for the same individual. 
communication; Clarke, 1980; Cherel, 2003; GBIF, 2016; OBIS, 2016) lying between the North Subtropical Front and the Polar Front (Kostianoy et al., 2003, 2004). Our findings suggest that the distribution of $A$. $d u x$ is much wider than the 'bi-subtropical distribution' described by Nesis (2003). The nutrient-poor waters of the Indian Ocean Subtropical Gyre province, characterized by high heat content, deep propagation of warm waters and oligotrophic conditions (Jayne \& Marotzke, 2002; Gouretski \& Koltermann, 2004; Longhurst, 2007), likely represent the northern border of the giant squid habitat in the Indian Ocean.

The majority of Indian Ocean $A . d u x$ have been described from squid remains discovered in predators' stomachs, mainly sperm whales (Clarke, 1980; Mikhalev et al., 1981; Nesis et al., 1985; Yukhov, 2014) and to a lesser extent sleeper sharks Somniosus sp. (Cherel, 2003), swordfish Xiphias gladius (Wendy West $^{3}$, unpublished data) and several albatross species Diomedea spp. (Cherel et al., 2002; Cherel, 2003). Similarly, two $A$. dux remains found floating at the surface (Cherel, 2003) also showed signs of predation by sperm whales and an unknown predator. We suggest that the giant squid described here was severely mutilated due to predation. The whole tail of the specimen was most likely severed by a predator, rather than other means of injury (e.g. propeller of a vessel), given the preferences of giant squid to deep-water habitats (Kubodera \& Mori, 2005) and visible patterns of tissue damage (Figure $1 \mathrm{~A}$ ). Injuries at the mantle tip (Figure $1 \mathrm{~A}$ ) suggest predation by a large animal, probably a sperm whale, as they are known to prey on giant squid and regularly occur within the region (Clarke, 1980; Jefferson et al., 1993; Mannocci et al., 2014), or possibly a great white shark (Carcharodon carcharias), which occasionally visit Reunion Island waters (Zuffa et al., 2002; Jaquemet, unpublished data). Smaller predators such as squid or fish leave predation marks that differ in size and shape from the ones observed here (Chapman et al., 2006; Lowry et al., 2009; Papastamatiou et al., 2010).

The present record complements the current knowledge on A. $d u x$ distribution and biology on regional and global scales. We document a rare occurrence of giant squid in tropical waters of the Indian Ocean and one of the largest individuals ever reported worldwide. Architeuthis dux remains an enigmatic species requiring more scientific efforts to address the current challenges in the understanding of its natural history, its role in ocean ecosystems and the potential threats to its conservation, especially those due to human activities (Guerra et al., 2011; Leite et al., 2016).

\section{SUPPLEMENTARY MATERIAL}

The supplementary material for this article can be found at https://doi.org/10.1017/Soo25315417001588.

\section{ACKNOWLEDGEMENTS}

We are grateful to Loïc Jauneau, the captain and Joel Mussard, the deckhand of FV 'Maeva 4' for their effort to collect the giant squid individual. Specific thanks to Thibaut Thellier for the preservation of the specimen and for providing photographs

${ }^{3}$ Department of Agriculture Forestry and Fisheries (DAFF), Cape Town, South Africa. and information associated with $A$. dux capture. Thomas Poirout and Sophie Bureau (Université de La Réunion) helped in meristic counts and morphometric measurements. Thanks to Yves Cherel (CNRS, France) for the comparative measurements of the beak and the validation of the species identification based on beak morphology. Tom Gilbert (Geological Museum, Copenhagen, Denmark) provided support in genetic identification. Charles G. M. Paxton (University of St Andrews, UK) provided DML and PI estimates from LRL based on his regression formula. Particular thanks are due to Dr Valentin Yukhov who shared detailed data on the historical occurrences of giant squid in sperm whale stomachs in the Indian Ocean, and to Wendy West for her data on giant squid beaks occurrence in swordfish stomachs. Finally, we thank Anne-Elise Nieblas who provided editing of the English. The insightful comments of two anonymous referees improved the manuscript.

\section{REFERENCES}

Benson D.A., Clark K., Karsch-Mizrachi I., Lipman D.J., Ostell J. and Sayers E.W. (2014) GenBank. Nucleic Acids Research (Database issue) 42, 32-37. doi: 10.1093/nar/gkt1030.

Berzin A.A. (1971) Kashalot. Moscow, 'Pischepromizdat'. [In Russian]

Berzin A.A. (1972) The sperm whale. Jerusalem: Israel Program for Scientific Translation.

Chapman L., Sharples P., Brogan D., Desurmont A., Beverly S. and Sokimi W. (2006) Marine species identification manual for horizontal longline fishermen/Manuel d'identification des espèces marines destiné aux pêcheurs à la palangre horizontale. Noumea, New Caledonia: Secretariat of the Pacific Community, xi, $152 \mathrm{pp}$.

Cherel Y. (2003) New records of the giant squid Architeuthis dux in the southern Indian Ocean. Journal of the Marine Biological Association of the United Kingdom 83, 1295-1296. doi: 10.1017/So025315403008695.

Cherel Y., Weimerskirch H. and Trouvé C. (2002) Dietary evidence for spatial foraging segregation in sympatric albatrosses (Diomedea spp.) rearing chicks at Iles Nuageuses, Kerguelen. Marine Biology 141, $1117-1129$

Clarke M.R. (1980) Cephalopoda in the diet of sperm whales of the southern hemisphere and their bearing on sperm whale biology. Discovery Reports 37, 1-324.

Clarke M.R. (1986) A handbook for the identification of cephalopod beaks. Oxford: Clarendon Press.

Coro G., Magliozzi C., Ellenbroek A. and Pagano P. (2015) Improving data quality to build a robust distribution model for Architeuthis dux. Ecological Modelling 305, 29-39. doi: 10.1016/j.ecolmodel.2015.03.011.

Frost N. (1936) A further species of giant squid (Architeuthis sp.) from Newfoundland waters. Annual Report of the Newfoundland Fishery Research Commission for 1935 2, 89-95.

Gauldie R.W., West I.F. and Förch E.C. (1994) Statocyst, statolith, and age estimation of the giant squid Architeuthis kirki. Veliger 37, 93-109.

GBIF (2016) Global Biodiversity Information Facility (GBIF) Data Portal. http://www.gbif.org/ (accessed 13 July 2016).

GEBCO (2016) The GEBCO_2014 Grid, version 20150318. http://www. gebco.net.

Geller J.B., Meyer C.P., Parker M. and Hawk H. (2013) Redesign of PCR primers for mitochondrial cytochrome $\mathrm{c}$ oxidase subunit I for marine invertebrates and application in all-taxa biotic surveys. Molecular Ecology Resources 13, 851-861. doi: 10.1111/1755-0998.12138. 
Gouretski V.V. and Koltermann K.P. (2004) WOCE Global Hydrographic Climatology. A Technical Report. Berichte des Bundesamtes für Seeschifffahrt und Hydrographie, 35, $52 \mathrm{pp}$.

Grist E.P.M. and Jackson G.D. (2007) How long would it take to become a giant squid? Reviews in Fish Biology and Fisheries 17, 385-399. doi: 10.1007/s11160-007-9046-x.

Guerra Á., González Á., Pascual S. and Dawe E.G. (2011) The giant squid Architeuthis: an emblematic invertebrate that can represent concern for the conservation of marine biodiversity. Biological Conservation 144, 1989-1997.

Hansel H.C., Duke S.D., Lofy P.T. and Gray G.A. (1988) Use of diagnostic bones to identify and estimate original lengths of ingested prey fishes. Transactions of the American Fisheries Society 117, 55-62.

Heuvelmans B. (1968) In the wake of the sea-serpents. 2nd edition. New York, NY: Hill \& Wang, 645 pp.

IHO (International Hydrographic Organization) (1953) Limits of oceans and seas. 3rd edition. International Hydrographic Organization, Monaco, Special Publication (S-23), no. 23, 38 pp.

Jayne S.R. and Marotzke J. (2002) The oceanic eddy heat transport. Journal of Physical Oceanography 32, 3328-3345.

Jefferson T.A., Leatherwood S. and Webber M.A. (1993) Marine mammals of the world. FAO species identification Guide. Rome: FAO.

Kameda Y., Kubodera T. and Wada T. (2015) Architeuthis dux mitochondrial $\mathrm{COX}_{1}$ gene for cytochrome $\mathrm{c}$ oxidase subunit 1 , partial cds, specimen_voucher: NSMT:DNA:41016. Direct Submission. Submitted (14-May-2015). Tsukuba: National Museum of Nature and Science, Center for Molecular Biodiversity Research.

Keil A. (1963) Riesentintenfische aus dem Pottwal-Magen. Natur und Museum 93, 319-323.

Kirk T.W. (1880) On the occurrence of giant cuttlefish on the New Zealand coast. Transactions and Proceedings of the New Zealand Institute 1879 12, 310-313.

Kirk T.W. (1882) Descriptions of new cephalopods. Transactions and Proceedings of the New Zealand Institute 1881 14, 283-286.

Kirk T.W. (1888) Brief description of a new species of large decapod (Architeuthis longimanus). Transactions and Proceedings of the New Zealand Institute 1887 20, 34-39.

Kostianoy A.G., Ginzburg A.I., Frankignoulle M. and Delille B. (2004) Fronts in the Southern Indian Ocean as inferred from satellite sea surface temperature data. Journal of Marine Systems 45, 55-73.

Kostianoy A.G., Ginzburg A.I., Lebedev S.A., Frankignoulle M. and Delille B (2003) Fronts and mesoscale variability in the Southern Indian Ocean as inferred from the TOPEX/POSEIDON and ERS-2 altimetry data. Oceanology 43, 671-682.

Kubodera T. and Mori K. (2005) First-ever observations of a live giant squid in the wild. Proceedings of the Royal Society B: Biological Sciences 272, 2583-2586. doi: 10.1098/rspb.2005.3158.

Landman N.H., Cochran J.K., Cerrato R., Mak J., Roper C.F.E. and Lu C.C. (2004) Habitat and age of the giant squid (Architeuthis sanctipauli) inferred from isotopic analyses. Marine Biology 144, 685-691.

Leite L., Campbell D., Versiani L., Nunes J.A.C.C. and Thiele T. (2016) First report of a dead giant squid (Architeuthis dux) from an operating seismic vessel. Marine Biodiversity Records 9, 1-3.

Leray M., Yang J.Y., Meyer C.P., Mills S.C., Agudelo N., Ranwez V., Boehm J.T. and Machida R.J. (2013) A new versatile primer set targeting a short fragment of the mitochondrial COI region for metabarcoding metazoan diversity: application for characterizing coral reef fish gut contents. Frontiers in Zoology 10, 34. doi: 10.1186/ 1742-9994-10-34.
Lipiński M.R. (1997) Morphology of giant squid Architeuthis statoliths. South African Journal of Marine Science 18, 299-303.

Longhurst A. (2007) Ecological geography of the sea. 2nd edition. San Diego, CA: Academic Press.

Lordan C., Collins M.A. and Perales-Raya C. (1998) Observations on morphology, age and diet of three Architeuthis caught off the west coast of Ireland in 1995. Journal of the Marine Biological Association of the United Kingdom 78, 903-917.

Lowry D., de Castro A.L.F., Mara K., Whitenack L.B., Delius B., Burgess G.H. and Motta P. (2009) Determining shark size from forensic analysis of bite damage. Marine Biology 156, 2483-2492.

Madden T. (2013) The BLAST sequence analysis tool. In Beck J., Benson D., Coleman J., Hoeppner M., Johnson M., Maglott D., Mizrachi I., Morris R., Ostell J., Pruitt K., Rubinstein W., Sayers E., Sirotkin K. and Tatusova T. (eds) The NCBI handbook [Internet]. 2nd edition. Bethesda, MD: National Center for Biotechnology Information (US). https://www.ncbi.nlm.nih.gov/books/NBK153387/.

Mannocci L., Laran S., Monestiez P., Dorémus G., Van Canneyt O. Watremez P. and Ridoux V. (2014) Predicting top predator habitats in the Southwest Indian Ocean. Ecography 37, 261-278. doi: 10.1111/ j.1600-0587.2013.00317.x.

Martins R.S. and Alvarez Perez J.A. (2009) A new record of giant squid Architeuthis sp. (Cephalopoda: Oegopsida) in Brazilian waters. Zoologia 26, 613-623. doi: 10.1590/S1984-46702009005000012.

McClain C.R., Balk M.A., Benfield M.C., Branch T.A., Chen C., Cosgrove J., Dove A.D.M., Gaskins L.C., Helm R.R., Hochberg F.G., Lee F.B., Marshall A., McMurray S.E., Schanche C., Stone S.N. and Thaler A.D. (2015) Sizing ocean giants: patterns of intraspecific size variation in marine megafauna. PeerJ 3, e715, 1-69. doi: $10.7717 /$ peerj. 715 .

Mikhalev J.A., Savusin V.P., Kishiyan N.A. and Ivashin M.V. (1981) To the problem of the feeding of sperm whales from the southern hemisphere. Reports of the International Whaling Commission 31, 737-745.

Nesis K.N. (2003) Distribution of recent Cephalopoda and implications for Plio-Pleistocene events. Berliner Paläobiologische Abhandlungen 4, 199-224.

Nesis K.N., Amelekhina A.M., Boltachev A.R. and Shevtsov G.A. (1985) Records of giant squids of the genus Architeuthis in the North Pacific and South Atlantic. Zoologicheskii Zhurnal 64, 518-528. [In Russian]. Also available as: English translations of selected publications on Cephalopods by Kir N. Nesis. 2003. Volume I. Part 2. Selected translated publications, 1965-1994. Compiled by M.J. Sweeney. Washington, DC: Smithsonian Institution Libraries, pp. 685-697.

Nigmatullin C.M. (1976) Discovery of giant squid of the genus Architeuthis in Atlantic equatorial waters/O nakhodke gigantskogo kal'mara Architeuthis v ehkvatorialnykh vodakh Atlanticheskogo okeana. Biologiya Morya 4, 29-31. [In Russian]

Norman M.D. and Lu C.C. (1997) Sex in giant squid. Nature 389, 683-684

OBIS (2016) Distribution records of Architeuthis dux Steenstrup, 1857. Available: Ocean Biogeographic Information System. Intergovernmental Oceanographic Commission of UNESCO. https://www.iobis.org. (accessed 13 July 2016)

Papastamatiou Y.P., Wetherbee B.M., O'Sullivan J., Goodmanlowe G.D. and Lowe C.G. (2010) Foraging ecology of cookiecutter sharks (Isistius brasiliensis) on pelagic fishes in Hawaii, inferred from prey bite wounds. Environmental Biology of Fishes 88, 361-368.

Paxton C.G.M. (2016) Unleashing the Kraken: on the maximum length in giant squid (Architeuthis sp.). Journal of Zoology 300, 82-88. doi: 10.1111/jzo.12347.

Potier M., Ménard F., Benivary H.D. and Sabatié R. (2011) Length and weight estimates from diagnostic hard part structures of fish, crustacea 
and cephalopods forage species in the western Indian Ocean Environmental Biology of Fishes 92, 413-423. doi: 10.1007/ s10641-011-9848-5.

Ratnasingham S. and Hebert P.D.N. (2007) BOLD: the barcode of life data system (www.barcodinglife.org). Molecular Ecology Notes 7, 355-364. doi: 10.1111/j.1471-8286.2006.01678.x.

Re M.E., Baron P.J., Beron J.C., Gosztonyi A.E., Kuba L., Monsalve M.A. and Sardella N.H. (1998) A giant squid Architeuthis sp. (Mollusca, Cephalopoda) stranded on the Patagonian shore of Argentina. South African Journal of Marine Science 20, 109-122.

Roeleveld M.A.C. (2000) Giant squid beaks: implications for systematics Journal of the Marine Biological Association of the United Kingdom 80, $185-187$.

Roper C.F.E. and Boss K.J. (1982) The giant squid. Scientific American 246, 96-105.

Roper C.F.E., Judkins H., Voss N.A., Shea E., Dawe E., Ingrao D., Rothman P.L. and Roper I.H. (2015) A compilation of recent records of the giant squid, Architeuthis dux (Steenstrup, 1857) (Cephalopoda) from the Western North Atlantic Ocean, Newfoundland to the Gulf of Mexico. American Malacological Bulletin 33, 78-88. doi: 10.4003/006.033.0116.

Roper C.F.E. and Voss G.L. (1983) Guidelines for taxonomic descriptions of cephalopod species. Memoirs of the National Museum of Victoria 44, $49-63$.

Schrope M. (2013) Giant squid filmed in its natural environment Landmark achievement reveals clues to mollusc's behaviour. Nature News (14 January 2013). doi: 10.1038/nature.2013.12202.

Silas E. (1968) Cephalopoda of the west coast of India collected during the cruises of the research vessel Varuna, with a catalogue of the species known from the Indian Ocean. In Rao K.V. (ed.) Proceedings of the Symposium on Mollusca held at Cochin from January 12 to 16, 1968 Marine Biological Association of India, Volume 1, pp. 277-359.

Silas E. (ed.) (1985) Cephalopod bionomics, fisheries and resources of the exclusive economic zone of India. CMFRI Bulletin 37.

Staub F. (1993) Requin bleau, calmar geant et cachalot. Proceedings of the Royal Society of Arts and Sciences of Mauritius 5, 141-145. 2 plates.

Staudinger M.D., Juanes F. and Carlson S. (2009) Reconstruction of original body size and estimation of allometric relationships for the longfin inshore squid (Loligo pealeii) and northern shortfin squid (Illex illecebrosus). Fishery Bulletin 107, 101-105.

Sweeney M.J. and Roper C.F.E. (2001) Records of Architeuthis specimens from published reports. http://invertebrates.si.edu/cephs/archirec.pdf.

Vélain C. (1877) Passage de Venus sur le Soleil (9 Décembre 1874). Expédition Française aux Iles Saint-Paul et Amsterdam. Zoologie. Observations générales sur la faune des deux iles suivies d'une description des Mollusques. Archives de Zoologie Expérimentale et Générale 6, 1-144, 9 figures, 5 plates.

Wada T., Kubodera T., Yamada M. and Terakado H. (2015) First records of small-sized young giant squid Architeuthis dux from the coasts of Kyushu Island and the south-western Sea of Japan. Marine Biodiversity Records 8, e153, 1-8. doi: 10.1017/S175526721500127X.

Winkelmann I., Campos P.F., Strugnell J., Cherel Y., Smith P.J., Kubodera T., Allcock L., Kampmann M.-L., Schroeder H., Guerra A., Norman M., Finn J., Ingrao D., Clarke M. and Gilbert M.T.P. (2013) Mitochondrial genome diversity and population structure of the giant squid Architeuthis, genetics sheds new light on one of the most enigmatic marine species. Proceedings of the Royal Society B: Biological Sciences 280, 20130273. doi: 10.1098/rspb.2013.0273.

Xavier J.C. and Cherel Y. (2009) Cephalopod beak guide for the Southern Ocean. Cambridge: British Antarctic Survey, 129 pp.

Yukhov V.L. (1974) Discoveries of giant squids/Nakhodki gigantskikh kalmarov. Priroda (Moscow, Russia) 6, 60-63. [In Russian]

Yukhov V.L. (2014) Giant squids of Architeuthis genus in the Southern Ocean/Gigantskie kalmary roda Architeuthis v yuzhnom okeane. Ukrainian Antarctic Journal 12, 242-253. [In Russian]

and

Zuffa M., Van Grevelynghe G., De Maddalena A. and Storai T. (2002) Records of the white shark, Carcharodon carcharias (Linnaeus, 1758), from the western Indian Ocean. South African Journal of Science 98 , $347-349$.

\section{Correspondence should be addressed to:}

E.V. Romanov

CAP RUN, Magasin no 10 - Port Ouest, 97420 Le Port, Île de la Réunion, France email: evgeny.romanov@ird.fr 